\title{
EDITORIAL
}

\section{O DESAFIO DE LIDAR COM A VIOLÊNCIA NO SETOR SAÚDE}

\author{
Jonas Melman ${ }^{1}$, Rita de Cássia de Almeida Cruz ${ }^{2}$
}

Em nossos tempos, a violência se transformou em um problema central para humanidade. Os problemas relativos ao fenômeno violento ganham cada vez mais visibilidade no Brasil, tornando-se uma questão importante para a saúde coletiva; o setor saúde é responsável pelo cuidado e reabilitação das pessoas em situação de violência, assim como pela elaboração de estratégias de prevenção.

Reconhecer que a violência é um problema prioritário a ser enfrentado pelo setor saúde constitui um grande avanço. A complexidade do fenômeno exige abordagem intersetorial, que procure formular projetos que envolvam todos os setores da sociedade. Isoladamente, não é possível realizar um processo de construção de uma sociedade mais pacífica e solidária. O setor saúde precisa aprender a trabalhar em parceria com a educação, justiça, segurança, meio ambiente, conselhos tutelares e serviço social.

O estabelecimento de uma rede de cuidados integrais às pessoas em situação de violência, articulada com outras redes sociais, implica em investimentos na organização e gestão dos serviços de saúde. Também implica na capacitação dos profissionais para identificar e acolher pessoas envolvidas com o problema, além de realizar ações de promoção da cultura de paz e não-violência. Muitas vítimas ainda passam silenciosas pelos diversos serviços de assistência. Nesse sentido, uma rede de cuidados consistente exige profissionais habilitados e motivados para a tarefa.

A existência de um sistema de informação de qualidade constitui instrumento relevante para avaliar e monitorar o impacto da violência nos serviços de saúde, bem como fornecer subsídios para a formulação de políticas públicas que atendam as necessidades da população. Lidar com a violência no setor saúde implica em mobilizar defesas e resistências por parte dos profissionais e dos gestores. Vivemos em uma sociedade que legitima a violência como instrumento para resolver conflitos entre pessoas, grupos ou organizações.

Da mesma forma, se observa violência nos serviços de saúde, principalmente nas relações entre os profissionais, e nas relações entre profissionais e usuários. É preciso resgatar o valor do diálogo e da negociação.

A cultura da violência suscita medos e insegurança, inclusive nos trabalhadores da saúde. A subnotificação dos casos de violência e a omissão de cuidado representam expressões das dificuldades a serem superadas.

A formação acadêmica, das mais diferentes profissões, ainda não prepara de maneira satisfatória os futuros profissionais para lidar com a violência; sensibilizar e capacitar para a complexidade da tarefa é um desafio da Universidade.

Assumir a responsabilidade pelo cuidado às pessoas em situação de violência representa um salto qualitativo para a atenção em saúde. Investir na prevenção da violência nas relações entre profissionais, e destes com os usuários contribui para humanizar a saúde.

Existe, comprovadamente, forte correlação entre violência e produção ou agravamento de doenças. Trabalhar para mudanças de valores e atitudes é chave para minimizar muitos transtornos físicos e mentais. Trata-se de um convite para elaborar novas possibilidades de olhar, descobrir novas formas de lidar com os conflitos, e reinventar modalidades de convivência.

\footnotetext{
${ }^{1}$ Médico psiquiatra. Mestre em Medicina Preventiva. Assessor da Área Técnica de Cultura de Paz, Saúde e Cidadania da Secretaria Municipal de São Paulo. Responsável pela elaboração das políticas públicas do setor saúde para a superação da violência na cidade de São Paulo.

${ }^{2}$ Psicóloga. Mestre em Educação. Consultora de programas de formação em políticas para superação de violência.
} 


\title{
EDITORIAL
}

\section{THE CHALLENGE OF DEALING WITH VIOLENCE IN THE HEALTH SECTOR}

\author{
Jonas Melman ${ }^{1}$, Rita de Cássia de Almeida $\mathrm{Cruz}^{2}$
}

Nowadays violence has become a central problem to humanity. Problems related with the violent phenomenon gain more visibility in Brazil, and become an important question to public health. The health sector is responsible both for caring and rehabilitation of people within a violent setting, and for the development of prevention strategies.

It is of great advance to recognize that violence is a primordial matter to be faced by the health sector. The complexity of the phenomenon demands an intersectional attempt, which includes the development of projects involving every sectors of the society. Alone, no sector can make it possible to accomplish the construction process of a more peaceful society with more solidarity among its citizens. The health sector needs to learn to work in partnerships with the educational, justice, safety, environment, tutelary councils and social service areas.

The establishment of a network towards integral care to people in violent settings, which could be integrated with other social networks, demands financing for the organization and management of the health services. It also demands professional training regarding the identification and admission of people involved with this problem, besides the accomplishment of actions which can promote peace and non-violent behavior. Many victims are silent, even during the care process in health services. A consistent care network demand skilled and motivated professionals to this task.

The existence of an information system with quality consists in a relevant tool in order to evaluate the violence impact and to manage it in the health services, as well as to give subsidies to the development of public policies in order to meet the population needs. To deal with violence in the health sector, the mobilization of defenses and resistances by professionals and managers is demanded. We live in a society that legitimizes violence as an instrument to resolve conflicts among people, groups or organizations.

We can equally observe violence in the health services, mainly in the relationships between professionals, and between professionals and users. There's a need to rescue the value of dialogue and negotiation.

The culture of violence raises fears and insecurity, including among health workers. The underreporting of violence cases and the omission of care represent expressions of difficulties to be overcome.

Only academic studies, of many different disciplines, still don't prepare future professionals in a satisfactory way, to deal with violence. The challenge of the University is to sensitize and to enable to the complexity of the task.

To assume responsibility on caring for people in violence settings represents a qualitative approach towards health care. An investment in violence prevention in relationships between professionals and between professionals and users contributes to the humanization of the health sector.

It can be verified that there is a strong correlation between violence and the production or the worsening of diseases. Working forward changes in values and attitudes is a key factor to minimize many physical and mental disorders. That's an invitation to develop new possibilities to observe, to discover a new way to deal with conflicts, and to reinvent models of living together.

\footnotetext{
${ }^{1}$ Médico psiquiatra. Mestre em Medicina Preventiva. Assessor da Área Técnica de Cultura de Paz, Saúde e Cidadania da Secretaria Municipal de São Paulo. Responsável pela elaboração das políticas públicas do setor saúde para a superação da violência na cidade de São Paulo.

${ }^{2}$ Psicóloga. Mestre em Educação. Consultora de programas de formação em políticas para superação de violência.
} 


\title{
EDITORIAL
}

\section{EL DESAFÍO DE LA VIOLENCIA EN SECTOR DE SALUD}

\author{
Jonas Melman ${ }^{1}$, Rita de Cássia de Almeida Cruz ${ }^{2}$
}

La violencia se ha volvido, en los tiempos actuales, un problema central para la hunanidad. Los problemas referentes al fenómeno violento tienen cada vez más visibilidad en Brasil, siendo una importante cuestión para la salud colectiva. El sector de salud es responsable por el cuidado y la reabilitación de las personas en situación de violencia, así como por la elaboración de estrategias de prevención.

Reconocer que la violencia es un problema prioritario y debe ser afrontado por el sector de salud constituye un gran avance. La complejidad de ese fenómeno exige un abordaje intersectorial a fin de formular proyectos que engloben todos sectores de la sociedad. Aisladamente no es posible realizar un proceso de construcción de una sociedade más pacífica y solidaria. El sector de salud necesita trabajar en sociedad con otros sectores, como de la educación, la justicia, la seguridad, el medio ambiente, el consejos tutelares y el servicio social.

El establecimiento de una red de cuidados integral a las personas en situación de violencia, articulado con otras redes sociales, significa inversiones en la organización y gestión de los servicios de salud. Implica, todavía, capacitación de profesionales que identifiquen y acojan personas involucradas en ese problema, además de realizar acciones de promoción de la cultura de paz y no violencia. Hay muchas víctimas que no son conocidas por los diversos servicios de asistencia. En ese sentido, una red de cuidados consistente exige profesionales habilitados y motivados para la tarea.

La existencia de un sistema de información de cualidad constituye un instrumento relevante para evaluar y fiscalizar el impacto de la violencia en los servicios de salud, así como fornecer subsidios para la elaboración de políticas públicas para atender a las necesidades de la población. Lidiar con la violencia en sector de salud implica movilizar defensas y resistencias de los profesionales y de los gestores. Vivimos en una sociedad que legitima la violencia como un instrumento de resolver conflictos entre personas, grupos u organizaciones.

Igualmente se observa violencia en los servicios de salud, principalmente en las relaciones entre los profesionales, y en las relaciones entre profesionales y usuarios. Por eso, es necesario rescatar el valor del diálogo y de la negociación.

La cultura de la violencia causa miedos e inseguridad, incluso en los trabajadores de la salud. La subnotificación de los casos de violencia y la omisión de cuidado representan expresiones de las dificultades que deben ser superadas.

La formación académica, entre las más distintas profesiones, todavía no prepara los futuros profesionales de modo satisfactorio para lidiar con la violencia; sensibilizar y capacitar para la complejidad de la tarea es un desafío de la Universidad.

Asumir la responsabilidad por el cuidado de las personas en situación de violencia representa un salto cualitativo para la atención en salud. Invertir en la prevención de la violencia en las relaciones entre profesionales y entre profesionales y usuarios contribuye para hunanizar la salud.

Hay, comprobadamente, una grande correlación entre violencia y producción o agraviamiento de enfermedades. Trabajar para cambios de valores y actitudes es una solución para minimizar muchos trastornos físicos y mentales. Esta es una invitación para elaborar nuevas posibilidades de mirar, descobrir nuevas formas de lidiar con los conflictos, así como reinventar modalidades de convivencia.

\footnotetext{
${ }^{1}$ Médico psiquiatra. Mestre em Medicina Preventiva. Assessor da Área Técnica de Cultura de Paz, Saúde e Cidadania da Secretaria Municipal de São Paulo. Responsável pela elaboração das políticas públicas do setor saúde para a superação da violência na cidade de São Paulo.

${ }^{2}$ Psicóloga. Mestre em Educação. Consultora de programas de formação em políticas para superação de violência.
} 